УДК 623.437

\title{
О.М. Рудковський
}

Академія сухопутних військ імені гетьмана Петра Сагайдачного, Львів

\section{ТРЕНАЖЕРНЕ ЗАБЕЗПЕЧЕННЯ СУХОПУТНИХ ВІЙСЬК ЯК МЕХАНІЗМ ПІДВИЩЕННЯ РІВНЯ БОЙОВОЇ ПІДГОТОВКИ МЕХАНІЗОВАНИХ ТА ТАНКОВИХ ПІДРОЗДІЛІВ}

\author{
У статті розглянуто проблемні питання забезпечення Сухопутних військ Збройних Сил України \\ новітніми тренажерними системами, проведено аналіз їх впливу на рівень бойової підготовки \\ механізованих та танкових підрозділів в умовах бюджетного обмеження.
}

Ключові слова: навчально-тренувальні засоби, комп'ютерно-технологічні системи, тренажерні системи, тренажерне виробниџтво, тренажерні технологї.

\section{Постановка проблеми}

Підвищена зацікавленість у тренажерній тематиці обумовлена зростаючим значенням тренажерів у бойовій підготовці сучасних збройних сил (ЗС). Значне ускладнення бойової техніки, засобів ii застосування у збройних конфліктах не дозволяє забезпечити необхідний рівень знань та навичок військових фахівців без практики бойової підготовки на сучасних навчально-тренувальних засобах (НТ3).

Визначаючи роль тренажерів у навчанні особового складу військових спеціалістів, слід акцентувати увагу на особливості людської психіки, а саме: для застосування складної військової техніки спеціалісту необхідні стійкі навички (спроможність виконувати складні операції та алгоритми бойової роботи без свідомої регуляції по елементах, тобто автоматично). Підраховано, що навіднику гармати танка для набуття відповідних навичок та доведення дій до автоматизму необхідно повторювати алгоритм бойової роботи до 400 разів.

Зауважимо, що для аналогічних дій 3 використанням бойової техніки для цього необхідні колосальні ресурси [1].

Аналіз обсягу завдань бойової підготовки та можливостей сучасних технологій показує: навіть сучасне покоління НТЗ вже надає можливість забезпечити вирішення 70-80\% завдань всього процесу навчання особового складу. Це достатньо високий рівень, тому що традиційна форма бойової підготовки, яка орієнтована, в основному, на бойові стрільби, заняття і навчання у полі, незважаючи на колосальні витрати, не в змозі забезпечити якісного вирішення навіть $30 \%$ завдань бойової підготовки. Тренажери не лише спроможні замінити затратні польові навчання, але й сприяти надбанню стійких навичок у поводженні 3 озброєнням, виключити випадки поламок бойової техніки під час невірних дій, суттєво зменшити витрати за рахунок економії палива та боєприпасів, ресурсу озброєння i військової техніки (ОВТ), забезпечити ефективний контроль тих, хто навчається, запобігти нещасним випадкам [2].

За оцінкою фахівців Центру дослідження армії, конверсії та роззброєння (ЦДАКР) без ретельної та добре організованої підготовки на тренажерах потенціал ОВТ буде використаний лише на 10-15\%. Таким чином, слід зазначити, що одним із шляхів удосконалення системи бойової підготовки $\epsilon$ впровадження в процес навчання військовослужбовців сучасних тренажерних систем (СТС) [5].

\section{Аналіз останніх досліджень і публікацій}

Провідні вчені у галузі тренажерного будівництва у своїх наукових роботах $[4,6]$ обгрунтовано довели необхідність та актуальність проведення невідкладних заходів щодо впровадження новітніх тренажерних систем навчання у програму бойової підготовки Збройних Сил України з подальшим iї інтегруванням у єдину систему навчання. Але в цих роботах не було акцентовано достатню увагу до конкретних видів та родів збройних сил (ЗС).

\section{Формулювання мети статті}

Метою статті є розгляд існуючого стану щодо забезпечення механізованих та танкових підрозділів Сухопутних військ (СВ) Збройних Сил України новітніми тренажерними системами та визначення ïх безпосереднього впливу на рівень бойової підготовки в умовах бюджетного обмеження. 


\section{Виклад основного матеріалу}

Стан розвитку тренажерного обладнання для збройних сил на світовому ринку. Протягом останніх років в провідних країнах світу погляди на роль і місце тренажерної підготовки в загальній системі навчання особового складу суттєво змінилися. Підготовка із використанням тренажерів стас основним атрибутом в професійній підготовці майже всіх категорій військових спеціалістів.

Сучасний світовий ринок військових тренажерів $\epsilon$ достатньо різноманітним за витратами та за призначенням. Безумовними лідерами у галузі тренажерного виробництва є такі країни, як США, ФРН, Ізраїль та Франція, які вже створюють складні тренажерні системи четвертого та п'ятого поколінь. В державах-членах НАТО діє закон, який вимагає здійснення постачання військової техніки тільки в комплекті із відповідним тренажерним обладнанням. Заняття на тренажерах у збройних силах цих країн $\epsilon$ невід'ємною складовою частиною бойової підготовки. На розробку та закупівлю НТЗ виділяються кошти в обсязі близько $10 \%$ від загальної суми військових бюджетів, що складає більше 10 млрд американських доларів. Сухопутні війська бундесверу нараховують близько 2,5 тис. одиниць тренажерів різного напрямку, економічний ефект від їх застосування оцінюється у суму більше 50 млн доларів. У Сухопутних військах США застосування тільки тренажерів бронетанкової техніки за рік привело до економії витрат близько 180 млн доларів.

Практичну користь застосування військових тренажерів було неодноразово підтверджено у всіх останніх локальних озброєних конфліктах (Ірак, Югославія, Афганістан). Існуючі військові тренажерні технології охопили практично всі завдання щодо відповідної підготовки військовослужбовців [8].

Окремо розглянемо досвід найближчого сусіда України - Російської Федерації (РФ). На початку 90-х років ії збройні сили знаходилися у стані, подібному до нашого сучасного. На даний момент у Міністерстві оборони РФ ведуться цілеспрямовані дослідження та розробки тренажерних систем, проведено об'єднання виробничих та інтелектуальних ресурсів в рамках підприємства «Тренажерні системи».

Розроблено Комплексну цільову програму щодо розвитку засобів навчання та підготовки ЗС РФ у період до 2020 року. Міноборони винятково відповідально відноситься до питань якості тренажерних засобів, що закуповують для збройних сил. На науково-дослідницькі роботи щодо розробки НТЗ виділяється 10 млрд 36 млн рублів, проте на закупівлю цих засобів - 22 млрд 620 млн [3].
Аналіз існуючого стану тренажерного забезпечення бойової підготовки механізованих та танкових підрозділів Сухопутних військ ЗС України. В Міністерстві оборони України до цього часу, на жаль, не сформований єдиний погляд на роль та місце тренажерів в бойовій підготовці збройних сил. Цей факт підтверджує відсутність будь-якої координації робіт із створення новітніх HT3.

Аналізуючи процес застосування СТC у підготовці механіків-водіїв та навідників гармат у CВ НАТО, РФ та України у відсотках спостерігаємо, що на тренажери відведено відповідно 80\%, 48\% та $36 \%$ занять (рис. 1 ).

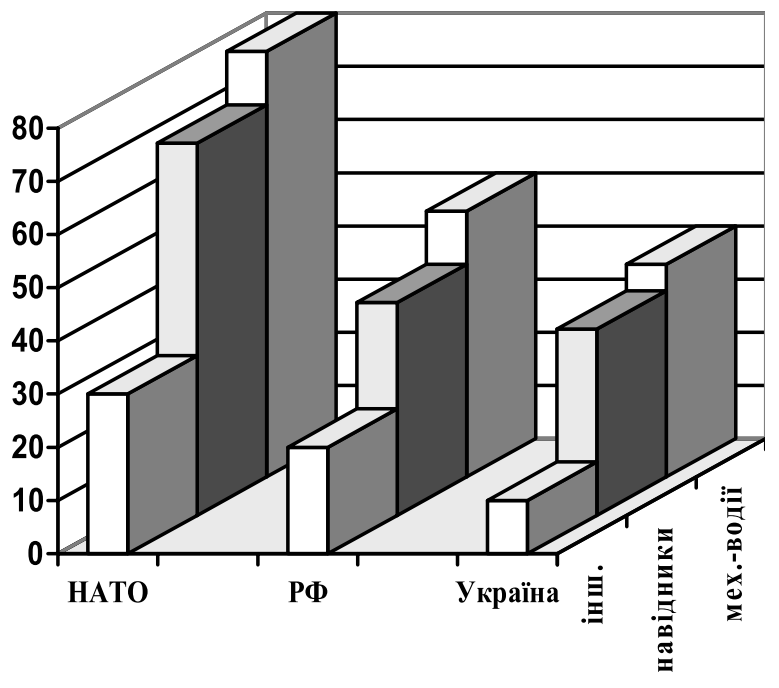

Рис. 1. Аналіз процесу застосування СТС у 3С

Зазначимо, що за кордоном оснащення військ сучасними тренажерами вирішується силами та засобами, кардинально відмінними від українських.

У Сухопутних військах ЗС України у розпорядженні командирів, які сьогодні організовують бойову підготовку механізованих та танкових підрозділів, знаходиться матеріальна база, яка була створена ще 20-30 років тому (тренажери типу 2 Х47, ТНТ, ТКНТ, ТНО, ТТВ та ін. - всі вони характеризується моральним та технічним старінням).

Станом на кінець 2010 року Сухопутні війська мали близько 90 одиниць застарілих тренажерів, $35 \% 3$ яких у непрацездатному стані, і лише 11 сучасних комплексних динамічних тренажерів підготовки екіпажів танка Т-64БВ та бойової машини піхоти БМП-2. 3 них шість зосереджено в Академії сухопутних військ, чотири - у навчальному центрі «Десна» та лише один - у бойовій частині.

Узагальнені дані про сучасний тренажерний парк СВ наведені (табл. 1): 
Табличя 1

Наявність тренажерів на забезпеченні механізованих і танкових підрозділів СВ

\begin{tabular}{|c|c|c|}
\hline $\begin{array}{c}\text { Тип } \\
\text { тренажера }\end{array}$ & $\begin{array}{c}\text { Назва } \\
\text { об'єкта }\end{array}$ & $\begin{array}{c}\text { Кількість, } \\
\text { од. }\end{array}$ \\
\hline КДТЕ & Т-64БВ & 6 \\
\hline КДТЕ & БМП-2 & 5 \\
\hline УКС & БТР-80 & 1 \\
\hline УКС & Т-64БВ & 8 \\
\hline УКС & БМП-2 & 6 \\
\hline УКС & БМП-1 & 4 \\
\hline УК & БМП-2 & 10 \\
\hline УК & БМП-1 & 4 \\
\hline УДС & Т-64А & 6 \\
\hline УДС & Т-64БВ & 3 \\
\hline УДС & БМП-2 & 4 \\
\hline УДС & БМП-1 & 3 \\
\hline УДС & БТР-80 & 6 \\
\hline ТКНТ-4 & Т-64 & 7 \\
\hline ТНО-765 & БМП & 12 \\
\hline ТТВ-447 & Т-64БВ & 21 \\
\hline ТТВ-219 & Т-64 & 3 \\
\hline ТТВ-765 & БМП-2 & 7 \\
\hline \multicolumn{2}{|l}{} & $\mathbf{1 0 6}$ \\
\hline Разом: & \\
\hline
\end{tabular}

Як результат, офіцери-випускники 3 отриманими навичками у володінні ОВТ після прибуття у війська вже як командири підрозділів розпочинають процес бойової підготовки на застарілій навчальній базі. Вони не мають можливості не тільки підтримувати на необхідному рівні свої навички, але й ефективно навчати свої підрозділи. При такому підході вирішити завдання щодо підвищення ефективності бойової підготовки стає неможливим [2].

За результатами інтерактивного опитування ЦДАКР серед військових експертів, 75\% 3 них відповіли, що рахують рівень підготовки СВ низьким i потребуючим негайного виділення ресурсів та технічних засобів. Вони бачать шлях виходу 3 ситуації, що склалася, у збільшенні фінансування, але це маловірогідне. Іншим та більш реальним шляхом підвищення якості бойової підготовки із збереженням існуючого рівня бюджетних асигнувань $\epsilon$ широке застосування у військах тренажерних комплексів. Для підтримання бойової підготовки на відповідному рівні необхідно скеровувати 10-15\% від загального фінансування військових розробок на створення СТЗ 3 їх закупівлею та постачанням у війська.

Розрахунки свідчать, що тільки для підготовки механіка-водія 3 класу (стаж практичного водіння не менше 180 км) за час навчання на техніці необхідно 3500 грн. За рік у військах вчаться близько 800 чоловік. Таким чином, для їх підготовки необхідно 2 млн 850 тис. грн. Сухопутні війська у своєму складі мають близько 600 механіків-водіїв танка Т-64БВ. На їх підготовку необхідно 3 млн 900 тис. грн. I це лише стосовно танкових підрозділів, не враховуючи підготовку екіпажів БМП, БТР, БРДМ та ін. Для порівняння зазначимо, що один сучасний комплексний тренажер підготовки екіпажу танка Т-64БВ коштує лише 1 млн 40 тис. грн. Не варто забувати й проте, що ресурс $80 \%$ основних зразків військової техніки та озброєння вже практично вичерпаний [8].

За підрахунками ЩДАКР, використання у системі бойової підготовки комплексних тренажерів приведе до економії пробігу бронетанкової техніки на 50-60\%, витрат боєприпасів - на 25-30\%. Впровадження в процес навчання механізованих та танкових підрозділів тренажерів тактичної підготовки складає економічний ефект за рік близько 15 млн доларів [5].

На рис. 2 представлений порівняльний аналіз витрат на бойову підготовку механізованої роти при традиційній формі навчання та 3 використанням сучасних НТ3:

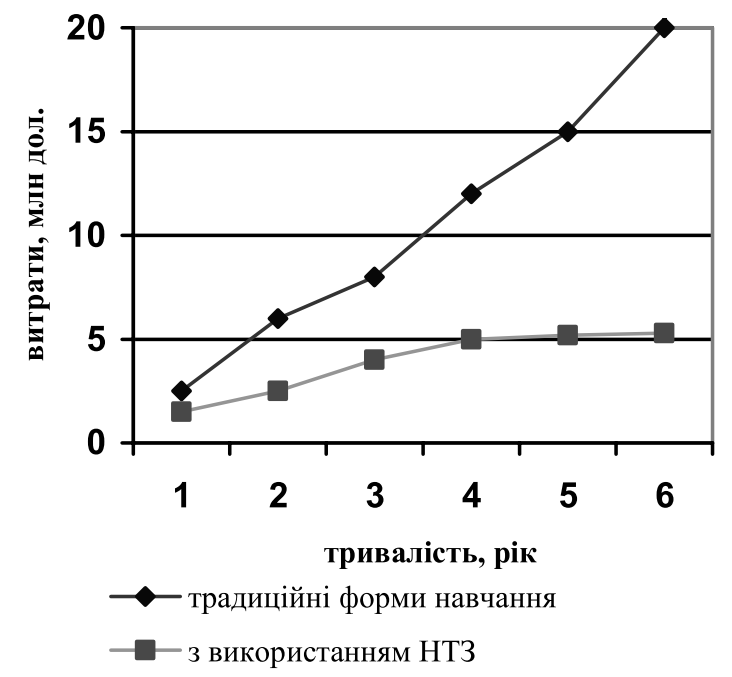

Рис. 2. Порівняльний аналіз витрат на бойову підготовку механізованої роти за період навчання

Проводячи аналіз впливу сучасних НТ3 на рівень набуття практичних навичок, наприклад, навідником гармати танка Т-64БВ, слід зазначити значні зміни в бік зменшення часу на виконання алгоритму бойової роботи. На рис. 3 зображено час виконання алгоритму при використанні традиційних форм навчання та 3 використанням сучасних тренувальних засобів. 


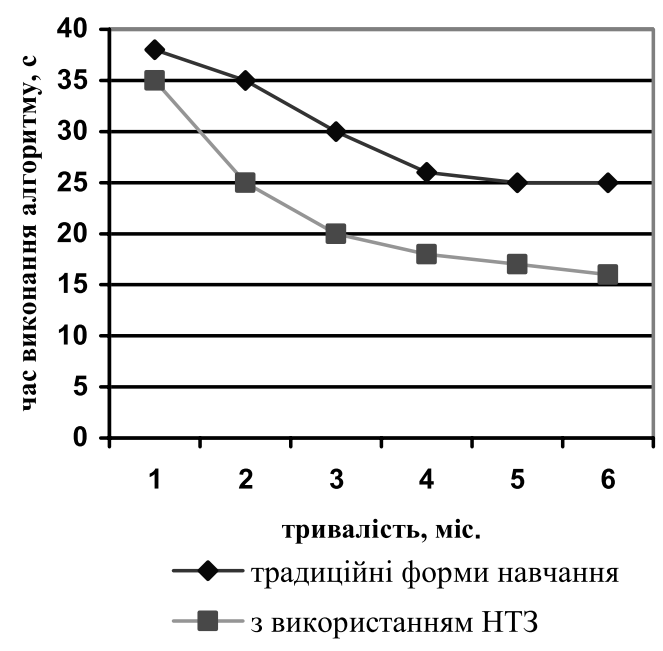

Рuc. 3. Порівняльний аналіз часу на виконання алгоритму бойової роботи навідником гармати

Таким чином, ми спостерігаємо, що застосування сучасних НТ3 у процесі бойової підготовки підрозділів $\mathrm{CB}$ здійснюе суттевий позитивний вплив на якісні та кількісні показники навчання.

Стан галузі тренажерного будівництва в Україні. В Україні тренажерне будівництво як галузь започатковано відносно недавно, за останніх 10-12 років, проте виключно за власною ініціативою окремих спеціалістів і підприємств.

Загалом, на сьогоднішній день в цій галузі працює близько 30 організацій, підприємств та науково-дослідних лабораторій: Харківське конструкторське бюро 3 машинобудівництва ім. А.А. Морозова (ХКБМ), АНТК ім. Антонова, Інститут системного аналізу i комп'ютернотехнологічних систем (ІСАКТС) Української академії наук, ТОВ «МАРКЕТ-МАТС», Спеціальне конструкторсько-технологічне бюро (СКТБ) Інституту проблем міцності, концерн «Техвоєнсервіс», НПП «Енергія 2000», НВП «МЕТЕКОЛ» та ін. Всі вони працюють абсолютно розрізнено, конкуруючи між собою та 3 аналогічними фірмами на зовнішньому ринку. Зазначимо, що внутрішнього ринку для виробників тренажерів на даний час немає. Однак далеко не всі вони можуть бути достатньо серйозними конкурентами на зовнішньому ринку тренажерів, хоча Україна вже відома на світовому ринку зброї завдяки постачанню військової техніки для Сухопутних військ [2].

В Україні практичним монополістом у галузі виробництва тренажерів для СВ $є$ ХКБМ, яке створило повнофункціональні комплексні тренажери для основного танка Сухопутних військ Т-64Б, танків Т-80УД, Т-84, бойової машини піхоти БМП-2, бронетранспортера БТР-3Е. Ведуться роботи щодо створення комплексних тренажерів для танків «Оплот» і «Булат» та нового бронетранспортера БТР-4.

Вони побудовані на базі сучасних комп'ютерних навчальних програм та мультимедійних засобів. Комплексні тренажери використовуються як автономно, так і об'єднаними в єдину мережу для групового навчання у складі підрозділу. За допомогою цього комплексу в інтерактивному режимі забезпечується повна адекватність функціонування вузлів і механізмів виробу, а також процес взаємодії з ними екіпажу під час виконання бойової роботи у штатних та позаштатних умовах. Програма здійснює вибір умов та режимів тренування та об'єктивний контроль дій тих, хто навчається, аналізує ефективність прийнятих рішень. Тренажери поєднані із динамічною платформою для відтворення коливань корпуса, відповідно до дій екіпажу та характеру місцевості [7].

Під час проведення тренувань дотримується основний принцип навчання - «від простого до більш складного».

Перспективи подальшого розвитку сучасних тренажерних технологій для забезпечення бойової підготовки військових спеціалістів Сухопутних військ. Проте сучасні умови вимагають вдосконалення навчально-тренувальних засобів, створення зразків четвертого та навіть п'ятого поколінь, із застосуванням новітніх тренажерних технологій.

«Напівнатурне моделювання». Напівнатурні тренажери (за західною класифікацією - virtual) створюються на базі сучасних електронних засобів та високотехнологічних комп'ютерів, технологій 3D-графіки, засобів візуалізації та мережевих технологій. Вони вибудовують 3 високою точністю алгоритми роботи зразків озброєння, військової техніки, відображають їх характеристики, а також сенсорно-моторне поле робочих місць екіпажів та динамічних характеристик озброєння.

У таких тренажерах органи керування реальні, штатні, а зовнішне середовище та алгоритм функціонування задаються програмним способом [3].

Використання таких тренажерів надає можливість вирішити наступні завдання бойової підготовки:

- підвищити якість технічної підготовки за рахунок практичної демонстрації тим, хто навчається, процесу функціонування як складових частин, так і зразків озбросння в цілому;

- підвищити якість розвідувальної підготовки за рахунок можливості практичного показу роботи оптичних, оптико-електронних, радіолокаційних 
приладів спостереження і прицілів у різноманітних умовах та режимах;

- формувати навички бойової роботи військовослужбовців шляхом багаторазового повторення як окремих найбільш складних операцій, так i алгоритмів бойової роботи на робочих місцях у різноманітних режимах роботи зразків озброєння та військової техніки в різних умовах під час виконання завдань;

- підтримувати навички бойової роботи на необхідному рівні за рахунок регулярних тренувань в умовах, що постійно ускладнюються;

- проводити бойове злагодження екіпажів (бойових розрахунків) за рахунок тренувань і занять у повному складі, під час яких екіпажі мають можливість виконувати розвідувальні та вогневі завдання в умовах, наближених до бойових;

- здійснювати бойове злагодження екіпажів під час двобічних тренажерних боїв.

«Імітаційне моделювання». Імітаційне моделювання (за західною класифікацією constractiv) засноване на описанні процесів бою математичними методами 3 використанням методу інтерактивного управління діями змодельованих підрозділів.

Такі технології надають можливість створення штабного тренажера, який $\epsilon$ системою розподіленого імітаційного моделювання загальновійськового бою, призначеного для відпрацювання і вдосконалення навичок командирів підрозділів в організації бойових дій, управлінні підрозділами та вогнем в бою. У процесі бойової підготовки штабний тактичний тренажер може використовуватись від двобічних двоступеневих (батальйон-рота) до чотирибічних чотириступеневих (батальйон-рота-взводвідділення) штабних тренувань 3 управління підрозділами та вогнем в бою. Використання у військах штабних тренажерів надасть можливість підвищити інтенсивність та якість тактичної підготовки командирів та штабних офіцерів Сухопутних військ [3].

Тренажери нового покоління мають ряд додаткових переваг:

- у 2-3 рази збільшують пропускну спроможність особового складу, тобто збільшують можливості щодо навчання;

- на 50\% зменшують витрати електроенергії;

- у 3-4 рази зменшують кількість сил та засобів, які залучаються до навчання;

- забезпечують компактне розміщення тренажерного комплексу.

Зауважимо, що за допомогою тренажерів навчання спеціалістів проводиться протягом 2-3 тижнів. На реальній техніці - 4-5. При цьому тренажери окуплять себе за 8-12 місяців їх експлуатації.
Використання комплексних динамічних тренажерів слід поєднувати із застосуванням комп'ютерних систем навчання. Вони призначені для теоретичної підготовки особового складу до роботи 3 озброєнням та військовою технікою. Електронні засоби навчання $\epsilon$ набором комп'ютерних програм, які реалізуються за допомогою проекторів. Програми надають можливість вивчити місцезнаходження органів керування або приладів, з'ясувати фізичну сутність роботи структурного елемента бойової машини, за допомогою тривимірної графіки здійснити віртуальне 3D-розбирання виробу. Паралельно 3 програмою використовується каталог з інструкціями 3 експлуатації та обслуговування техніки. Таким чином той, хто навчається, відразу розуміє сутність системи [2].

У сучасних умовах бойової підготовки механізованих та танкових підрозділів СВ інтенсивне використання сучасних тренажерів військового призначення обумовлено наступними основними факторами:

1. Значне ускладнення ОВТ, засобів їх бойового застосування, а також умов бойових дій.

2. Збільшення кількості аварій під час використання військової техніки, в тому числі під час навчань, що активізує використання тренажерів.

3. Підвищення вартості техніки, витрат на іiі утримання. Використання штатної техніки потребує значних затрат (боєприпаси, паливо тощо).

4. Поява технологій напівнатурних тренажерно-моделюючих систем дозволяє за допомогою сучасних тренажерів вирішувати все більший спектр завдань бойової підготовки, а деколи таких, що неможливо відпрацювати на реальних ОВТ.

5. Проблеми збереження екологічного середовища, що особливо актуально для густонаселених районів країни.

6. Тільки робота 3 тренажером надає можливість здійснювати ефективний контроль дій тих, хто навчається, та керувати процесом їх професійної підготовки [7].

Застосування в системі бойової підготовки військ тренажерних систем новітнього покоління дозволить підвищити ефективність результатів бойової підготовки військовослужбовців у 8-10 разів у порівнянні 3 традиційними формами та методами навчання, що засновані на використанні штатних зразків ОВТ та застарілого тренажерного обладнання. Воно приведе до скорочення витрат на бойову підготовку і збереження технічного ресурсу військової техніки на 60-70\%. Показники повноти та якості виконання операцій, а також алгоритмів бойової роботи екіпажів при цьому збільшаться 3 0,35 до 0,90 [8]. 


\section{Висновки}

Таким чином, зазначимо, що існуючий низький рівень забезпечення механізованих та танкових підрозділів Сухопутних військ Збройних Сил України новітніми тренажерними системами не дає можливості чіткої організації та якісного проведення занять 3 бойової підготовки.

Заняття та навчання із застосуванням ОВТ в умовах обмеженого фінансування стають досить проблематичними та не дають очікуваних високих результатів у підготовці військових спеціалістів.

Наведені вище приклади та розрахунки підтверджують гостру необхідність радикальних змін у технічній політиці щодо пріоритетів напрямку розвитку НТЗ. Проблема забезпечення занять 3 бойової підготовки комплексними тренажерними системами потребує державного підходу та вирішення у найкоротший термін. Від своєчасності прийняття відповідного рішення залежить рівень якості підготовки військових фахівців, їх знань та навичок, а в цілому i обороноздатність Збройних Сил України.

\section{Список літератури}

1. Гринченко С. Создатели вертуальности / С. Гринченко // Defense express-2010. - C. 34-38.

2. Луханін М. Потреба в сучасних навчальнотренувальних засобах надзвичайно велика / М. Луханін // Матеріали доповідей засідання круглого столу Центру дослідження армї̈, конверсії та роззброєння. - С. 36-37.
3. Матвісвський O. Тренажерні засоби спроможсні забезпечити бойову підготовку сухопутних військ / О. Матвієвський // Матеріали доповідей засідання круглого столу Центру дослідження армії, конверсії та роззброєння. - С. 47-49.

4. Матвієвський О. Методичний підхід до обтрунтування характеристик тренажерних засобів $i$ систем / О. Матвісвський // Наука і оборона. - 2005. C. $58-62$.

5. Підсумки виконання планів $і$ иляхи підвищення ефективності підготовки військ в умовах ресурсних обмежень. //Щорічник МО Украйни «Біла книга» - 2006. Оборонна політика Украӥни. - Київ: МО Украӥни, 2007. C. 27-29.

6. Руснак I. Проблеми модернізачії та створення тренажерно-моделювальних комплексів військового призначення / I. Руснак // Наука і оборона, 2002. - C. 32-34.

7. Смоляков В. Щоб перемагати у бою, потрібен інший рівень підготовки / В. Смоляков // Матеріали доповідей засідання круглого столу Центру дослідження армії, конверсії та роззброєння. - С. 50-51.

8. Фещенко А. Треножероманія / А. Фещенко // Defense express-2010 p. - C. 38-45.

Рецензент: А.М. Зубков, д.т.н., с.н.с., Академія сухопутних військ, Львів.

\title{
ТРЕНАЖЕРНОЕ ОБЕСПЕЧЕНИЕ СУХОПУТНЫХ ВОЙСК КАК МЕХАНИЗМ ПОВЫШЕНИЯ УРОВНЯ БОЕВОЙ ПОДГОТОВКИ МЕХАНИЗИРОВАННЫХ И ТАНКОВЫХ ПОДРАЗДЕЛЕНИЙ
}

\author{
О.М. Рудковский
}

В статье рассмотрены проблемные вопросы существующего положения по обеспечению Сухопутных войск Вооруженных Сил Украины новейшими тренажерными системами, проведен анализ их влияния на уровень боевой подготовки механизированных и танковых подразделений в условиях бюджетного ограничения.

Ключевые слова: учебно-тренировочные средства, компьютерно-технологические системы, тренажерные системы, тренажерное производство, тренажерные технологии.

\section{SIMULATION IN THE ARMY AS MECHANISM THAT INCREASES THE LEVEL OF MECHANIZED AND TANK FORMATIONS COMBAT TRAINING}

\section{O. Rudkovs'kyi}

The article considers problems of current provisions on the newest simulation systems in the Army of the Ukrainian Armed Forces. Also the analysis of simulation systems' influence on the level of mechanized and tank formations combat training in the conditions of budget constraint is conducted.

Keywords: training equipment, computer and technological systems, simulation systems, simulations, simulation technologies. 